\title{
Sławomir Błaż
}

Instytut Nafty i Gazu - Państwowy Instytut Badawczy

\section{Nowe rodzaje cieczy przemywających osady z płuczki inwersyjnej przed zabiegiem cementowania otworów wiertniczych}

\begin{abstract}
Cementowanie rur okładzinowych do ścian otworu jest niezwykle ważnym etapem w procesie wiercenia, uzależnionym przede wszystkim od właściwego oczyszczenia przestrzeni pierścieniowej z płuczki wiertniczej i powstałych w trakcie wiercenia osadów filtracyjnych. Jednym z głównych wymogów stawianych przed zabiegiem cementowania jest uzyskanie maksymalnie szczelnego wypełnienia przestrzeni pierścieniowej i trwałego połączenia między rurami a ścianą otworu. Odpowiednie przygotowanie otworu do zabiegu cementowania zakłada wytłoczenie płuczki i usunięcie ze ścian otworu powstałych osadów filtracyjnych i zanieczyszczeń. Proces oczyszczania otworu nabiera szczególnej wagi podczas zastosowania do wiercenia płuczki olejowodyspersyjnej. Płuczki olejowodyspersyjne to jedne z najmniej kompatybilnych cieczy wiertniczych z zaczynem cementowym. Nieprawidłowe wytłoczenie płuczki i pozostawienie nieusuniętej warstwy olejowej na ścianach otworu może być przyczyną zanieczyszczenia zaczynu cementowego płuczką, nieprawidłowego wypełnienia przestrzeni pierścieniowej przez zaczyn, zmniejszenia przyczepności związanego zaczynu cementowego do ściany otworu i rur okładzinowych, zmniejszonej integralności strukturalnej i słabej izolacji międzystrefowej. W artykule przedstawiono badania laboratoryjne nad opracowaniem składu cieczy przemywającej skutecznie rozpuszczającej i usuwającej zanieczyszczenia olejowe powstałe podczas wiercenia otworu po płuczce inwersyjnej przed zabiegiem cementowania kolumn rur okładzinowych. Opracowana ciecz przemywająca powinna charakteryzować się wysoką skutecznością oczyszczania osadów z płuczki olejowodyspersyjnej, być kompatybilna z płuczką wiertniczą i zaczynem cementowym oraz zapobiegać tworzeniu się emulsji wodno-olejowych. Zastosowanie nowo opracowanej cieczy przemywającej przed zabiegiem cementowania powinno także wpłynąć na zwiększenie przyczepności zaczynu cementowego do ścian otworu i lepsze wypełnienie przestrzeni pierścieniowej.
\end{abstract}

Słowa kluczowe: płuczka inwersyjna, ciecz przemywająca, ciecz rozdzielająca, osady płuczkowe.

\section{New types of preflush fluids removing invert emulsion drilling mud filter cake prior to casing cementing}

Casing cementing is an extremely important step in the drilling process, which is primarily dependent on the proper cleaning of the annular space, which involves the removal of drilling mud and filter cake. The main goals of cementing is to get the maximum/tightest filling of the annular space and a permanent connection between casing and wall. Proper preparation of the hole before the cementing operation involves removing of drilling mud from the hole and cleaning filter cake from the wall. Cleaning the borehole becomes particularly important when oil-based mud was used during drilling. This is due to the fact that the oil-based drilling muds are not very compatible with cement slurries. Incomplete removal of mud and leaving a layer of oil on the wall of the hole, can cause problems such as cement slurry pollution, improper filling of annular space, reduced adhesion between cement and wall, and reduced structural integrity. The article presents studies on the development of preflush fluid composition, which effectively dissolves and removes contaminants generated during drilling with invert emulsion drilling mud. Designed preflush fluid should be characterized by a high efficiency of filter cake, be compatible with drilling mud and cement slurry and prevent the formation of oil-in-water emulsion. The use of newly developed preflush fluid before cementing should also lead to increased adhesion of cement slurry to the wall and allow for better annular space filling.

Key words: invert emulsion drilling mud, preflush fluid, clean spacer, filter cake. 


\section{Wprowadzenie}

Płuczki inwersyjne stosowane są do wiercenia otworów w trudnych warunkach geologiczno-technicznych. W szczególności są zalecane do przewiercania formacji skał ilastołupkowych i solnych. Doskonała stabilizacja łupków, wysoka odporność na zanieczyszczenia oraz właściwości smarne to nieliczne $\mathrm{z}$ wielu zalet ich stosowania. Płuczki inwersyjne przyczyniają się do zwiększenia prędkości wiercenia, przedłużają czas pracy świdra oraz zmniejszają siłę adhezji (przyczepności) przewodu wiertniczego do osadu filtracyjnego na ścianie otworu wiertniczego. Pomimo wielu zalet płuczek olejowodyspersyjnych występują również niedogodności związane z ich stosowaniem, np. brak kompatybilności $\mathrm{z}$ cieczami wiertniczymi na osnowie wodnej, stosowanymi podczas cementowania otworu $[15,16]$.

Cementowanie rur okładzinowych do ścian otworu jest niezwykle ważnym etapem w procesie wiercenia, które jest przede wszystkim uzależnione od właściwego oczyszczenia przestrzeni pierścieniowej z płuczki wiertniczej i powstałych w trakcie wiercenia osadów filtracyjnych. Odpowiednie przygotowanie otworu do zabiegu cementowania zakłada wytłoczenie płuczki i usunięcie ze ścian otworu powstałych osadów filtracyjnych i zanieczyszczeń. Proces oczyszczania otworu nabiera szczególnej wagi podczas stosowana do wiercenia płuczki olejowodyspersyjnej. Zostaje wówczas zmieniona wodozwilżalność ścian otworu i rur okładzinowych, a na powierzchni ścian otworu pozostaje warstwa olejowa. Brak zgodności pomiędzy płuczką olejowodyspersyjną a wodnymi zaczynami cementowymi może być przyczyną nieprawidłowego wypełnienia przestrzeni pierścienio- wej przez zaczyn, zmniejszenia przyczepności związania zaczynu cementowego do ściany otworu i rur okładzinowych, zmniejszonej integralności strukturalnej i słabej izolacji międzystrefowej. W celu wyeliminowania wyżej wymienionej niezgodności po odwierceniu otworu płuczką inwersyjną do cementowania należy stosować zaczyny cementowe na osnowie emulsji lub trzeba przed zabiegiem cementowania przeprowadzić proces specjalnego oczyszczenia otworu. Poprawę jakości cementowania uzyskuje się poprzez sekwencyjne zatłaczanie do otworu cieczy przemywających, oczyszczających (rozpuszczalniki), cieczy o właściwościach zwilżających oraz cieczy rozdzielających (bufory) spełniających w otworze określoną funkcję. Zadaniem zatłaczanych cieczy wiertniczych jest wytłoczenie płuczki, oczyszczenie ścian otworu i osprzętu wiertniczego z powstałych w czasie wiercenia osadów filtracyjnych. Konwencjonalne metody oczyszczania otworu z płuczki olejowodyspersyjnej wymagają przepływu turbulentnego, zatłaczania dużej objętości cieczy oczyszczających i długich czasów płukania otworu $[3,5,7,8,11,12]$.

Alternatywą dla stosowania poszczególnych cieczy wiertniczych zatłaczanych sekwencyjnie do otworu jest możliwość opracowania przy udziale zestawu środków powierzchniowo czynnych uniwersalnej cieczy przemywającej (mikroemulsja), bez udziału toksycznych rozpuszczalników o właściwościach przemywających, oczyszczających i zwilżających. Poprzez dobór odpowiednich środków powierzchniowo czynnych możliwe jest także zmniejszenie objętości zatłaczanych cieczy i skrócenie czasów płukania otworu, zmniejszając przy tym ilość powstałych odpadów wiertniczych $[2,6,9,14,15]$.

\section{Mikroemulsje jako ciecze przemywające}

Stosunkowo nowym rozwiązaniem w oczyszczaniu otworu z płuczki olejowodyspersyjnej i jej osadów jest możliwość zastosowania technologii mikroemulsji, która pozwala na bardziej przyjazne dla środowiska działania (nie wymaga używania toksycznych rozpuszczalników, tj. benzen, toluen, ksylen) oraz ogranicza ilości stosowanych cieczy zabiegowych. Mikroemulsje są to termodynamicznie stabilne, optycznie przezroczyste roztwory składające się z dwóch niemieszających się cieczy. Od zwykłych emulsji różnią się one głównie tym, że można je wytwarzać przy niewielkim udziale energii mechanicznej. Mikroemulsja tworzy termodynamicznie stabilny system złożony z niepolarnej fazy olejowej, hydrofilowej fazy wodnej i środków powierzchniowo czynnych. Warstwy niepolarnej fazy olejowej i polarnej fazy wodnej rozdzielone są pojedynczą warstwą środka powierzchniowo czynnego. Dodatek środka

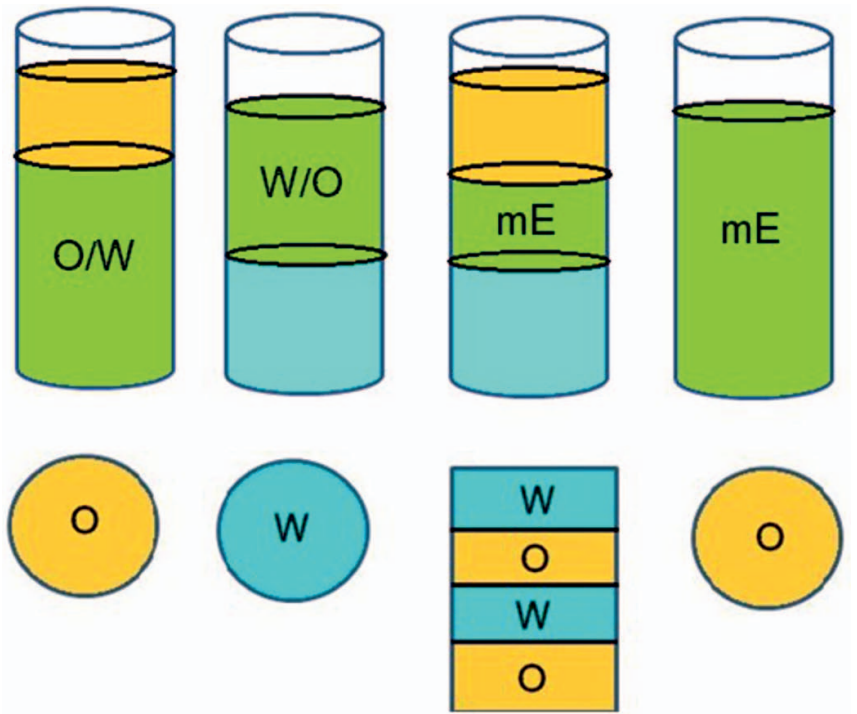

Rys. 1. Rodzaje mikroemulsji według Winsora [1] 
powierzchniowo czynnego wpływa na obniżenie napięcia powierzchniowego na granicy faz prawie do zera, co wywołuje spontaniczne mikroemulgowanie. Mikroemulsje tworzą zazwyczaj klarowne roztwory, ponieważ średnica kropelek fazy zdyspergowanej wynosi od 10 do $100 \mathrm{~nm}$. Dlatego też bardzo często określane są jako nanoemulsje. Mikroemulsje według definicji Winsora można podzielić na cztery kategorie $[1,2,6,9,15]$ :

a) Winsor I - mikroemulsja typu o/w (z nadmiarem fazy olejowej), b) Winsor II - mikroemulsja typu w/o (z nadmiarem fazy wodnej),

c) Winsor III - reprezentowana jest przez trzy fazy ciekłe będące w stanie równowagi. Mikroemulsję stanowi faza środkowa, która zawiera praktycznie całkowitą ilość surfaktantu oraz większość oleju i wody. Kolejne dwie fazy (w zależności od względnych gęstości): górna i dolna - zawierają pozostałą ilość oleju i wody,

d) Windsor IV - układ stanowi pojedynczą fazę transparentnej mikroemulsji [1, 2, 10, 13].

\section{Metody badawcze}

Badania doboru środków powierzchniowo czynnych prowadzono na podstawie danych dotyczących ich właściwości oraz określenia napięcia powierzchniowego. Badania napięcia powierzchniowego wodnych roztworów środków powierzchniowo czynnych oraz wytypowanych rozpuszczalników i olejów wykonano za pomocą tensjometru cyfrowego K9 firmy Krüss, metodą oderwania pierścienia du Noüya. Dobór środków powierzchniowo czynnych o właściwościach zwilżających przeprowadzano przy pomocy urządzenia pomiarowego goniometr OCA 15EC DataPhysics metodą kropli posadowionej. Pomiar kąta zwilżania wykonany został na metalowych płytkach ze stali P110 wyciętych i przygotowanych z rur okładzinowych. Składy opracowanych cieczy przemywających zostały wytypowane na podstawie przeprowadzonych badań określających stopień skuteczności wymywania osadów powstałych z płuczki inwersyjnej, z metalowej części rotora wiskozymetru Ofite 900. Test określania efektywności wymywania osadów płuczkowych z metalowej powierzchni rotora wiskozymetru jest jednym ze standardowych testów, za pomocą których możemy określić efektywność usuwania osadów z płuczki wiertniczej przez ciecze przemywające zarówno przed zabiegiem cementowania, jak również przy doborze cieczy przemywających stosowanych do oczyszczania złoża lub w trakcie procesu wymiany płuczki na ciecz nadpakerową. Badanie polega na zanurzeniu cylindra rotora symulującego powierzchnie rur okładzinowych w płuczce inwersyjnej i obracaniu go z prędkością 100 obr/min przez okres 30 minut. Po upływie założonego czasu oceniano wizualnie jakość i ilość naniesionego osa$\mathrm{du}$, a następnie zanurzano rotor wiskozymetru w cieczy przemywającej i poddawano obracaniu z prędkością 200 obr/min. Standardowa metodyka badań zakłada ocenę usunięcia osadu tylko z zewnętrznej części metalowej rotora. W przedstawionych badaniach oprócz wizualnego określenia skuteczności eliminacji osadu z zewnętrznej powierzchni rotora oceniano także wypłukanie osadów z przestrzeni pierścieniowej pomiędzy cylindrem rotora a bobem wiskozymetru oraz określano wagową ilość usuniętego osadu w cieczy przemywającej.
Dodatkowym testem określającym efektywność usuwania osadów płuczkowych przez ciecze przemywające była analiza przyczepności stwardniałego zaczynu cementowego do skały. Celem badań laboratoryjnych było określenie wpływu opracowanej cieczy przemywającej na przyczepność kamienia cementowego do skały po uprzednim oddziaływaniu płuczką olejowodyspersyjną, a następnie cieczami przemywającymi. Do badań laboratoryjnych stosowano próbki piaskowca pobranego z głębokości od około 300 do $400 \mathrm{~m}$. Osady na rdzeniach piaskowca tworzono z płuczki inwersyjnej o stosunku fazy olejowej do wodnej $80 \div 20$ i gęstości $1400 \mathrm{~kg} / \mathrm{m}^{3}$. Czas tworzenia osadu na rdzeniu piaskowca wynosił 1 godz. i określony został na podstawie wstępnych prób i obserwacji prowadzonych podczas testów przygotowujących próbki rdzenia do badań. Następnie, po wytworzeniu osadu na rdzeniach piaskowca, rozpoczęto proces oczyszczania przez przemywanie ich w odpowiednich cieczach z prędkością obrotową około $150 \mathrm{obr} / \mathrm{min}$. Zadany czas przemywania i usuwania osadu ustalono doświadczalnie na podstawie szeregu przeprowadzonych badań wstępnych. W zależności od zastosowanej technologii płukania otworu przed zabiegiem cementowania osad z próbki piaskowca oczyszczano za pomocą dwóch lub trzech cieczy przemywających. Po zastosowaniu do oczyszczania cieczy przemywających rdzenie piaskowca umieszczano wewnątrz pierścienia z tworzywa sztucznego. Następnie tak przygotowane rdzenie ze skały z wytworzonym osadem płuczkowym ustawiano współśrodkowo wewnątrz przygotowanych form i wypełniano zaczynem cementowym. Po sezonowaniu próbek przez okres 2 i 7 dni w temperaturze $50^{\circ} \mathrm{C}$ za pomoca maszyny wytrzymałościowej mierzono siłę zerwania przyczepności na kontakcie kamień cementowy-skała. Dla porównania otrzymanych wyników badań przeprowadzono pomiary przyczepności kamienia cementowego do skały wzorcowej bez naniesionego osadu filtracyjnego (próbka wzorcowa) oraz pomiary przyczepności kamienia cementowego do skały po wcześniejszym oddziaływaniu płuczki olejowodyspersyjnej z pominięciem zabiegów oczyszczania próbek przez ciecze przemywające [4]. 


\section{Badania nad opracowaniem składów cieczy przemywających}

Do sporządzania cieczy przemywających (mikroemulsji) użyto środków powierzchniowo czynnych o działaniu rozpuszczającym, solubilizacyjnym, myjącym, emulgującym oraz zwilżającym. Badania doboru środków powierzchniowo czynnych prowadzono na podstawie danych dotyczących ich właściwości oraz określania napięcia powierzchniowego. Po dokonaniu wstępnego doboru środków powierzchniowo czynnych, a także wyselekcjonowaniu emulgatorów, oleju i rozpuszczalników przystąpiono do badań łączenia wybranych środków chemicznych ze sobą w różnych kombinacjach jakościowych i ilościowych. Następnie przeprowadzono szereg badań laboratoryjnych określających efektywność usuwania osadów płuczkowych przez ciecze przemywające.

Oceny efektywności działania sporządzonych cieczy przemywających dokonywano na podstawie stopnia wymycia zanieczyszczeń z powierzchni metalowej rotora oraz wewnętrznej przestrzeni pierścieniowej pomiędzy bobem wiskozymetru a cylindrem rotora, a także w oparciu o wagową ilość usuniętego osadu. Niepewność pomiarów oszacowano na podstawie klasy dokładności przyrządów pomiarowych. Osady na powierzchni płytek metalowych oraz z powyższym kontynuowano badania nad zmianą składu cieczy przemywającej poprzez dobór nowych rodzajów środków chemicznych. Na podstawie przeprowadzonych badań ustalono, że do składu cieczy przemywających należy włączyć dodatek emulgatora oraz środka zwilżającego.

Badania nad doborem środków powierzchniowo czynnych o właściwościach zwilżających wykonano za pomocą goniometru OCA 15EC DataPhysics. Analizę kąta zwilżania przeprowadzono metodą kropli posadowionej na powierzchni metalowych płytek ze stali P110 wyciętych z rur okładzinowych. Do badań wytypowano środki wybrane na podstawie niskich wartości napięcia powierzchniowego. Wyniki pomiaru kąta zwilżania płytek metalowych z zaadsorbowaną na ich powierzchni substancją zestawiono w tablicy 3 .

Otrzymane na podstawie badań laboratoryjnych wartości kąta zwilżania różnią się miedzy sobą w zależności od zastosowanych środków chemicznych. Najniższe wartości kąta zwilżania uzyskaliśmy dla roztworu ID5, którego średni kąt zwilżania wyniósł $6,7^{\circ}$ (tablica 3 ). Bardzo dobrymi właściwościami zwilżającymi charakteryzowały się również środki

Tablica 1. Właściwości płuczki inwersyjnej zastosowanej do tworzenia osadów

\begin{tabular}{|c|c|c|c|c|c|c|c|c|c|}
\hline \multirow{2}{*}{$\begin{array}{l}\frac{\bar{z}}{N} \\
\frac{0}{2} \\
\frac{2}{2} \\
\frac{1}{Z}\end{array}$} & \multirow{2}{*}{\multicolumn{2}{|c|}{ Rodzaj płuczki }} & $\begin{array}{l}\text { Gęstość } \\
{\left[\mathrm{kg} / \mathrm{m}^{3}\right]}\end{array}$ & \multicolumn{2}{|c|}{$\begin{array}{l}\text { Lepkość } \\
{[\mathrm{mPa} \cdot \mathrm{s}]}\end{array}$} & \multirow{2}{*}{$\begin{array}{c}\begin{array}{c}\text { Granica } \\
\text { płynięcia } \\
{[\mathrm{Pa}]}\end{array} \\
\tau_{y} \\
\pm 0,75\end{array}$} & \multirow{2}{*}{$\begin{array}{c}\text { Wytrzymałość } \\
\text { strukturalna } \\
{[\mathrm{Pa}]} \\
\mathrm{I} / \mathrm{II} \\
\pm 0,05\end{array}$} & \multirow{2}{*}{$\begin{array}{c}\text { Filtracja } \\
{\left[\mathrm{cm}^{3}\right]} \\
\quad \pm 0,2\end{array}$} & \multirow{2}{*}{$\begin{array}{l}\text { ES } \\
{[\mathrm{V}]} \\
\pm 1\end{array}$} \\
\hline & & & $\begin{array}{c}\rho \\
\pm 5\end{array}$ & $\begin{array}{l}\eta_{p l} \\
\pm 1\end{array}$ & $\begin{array}{c}\eta_{s} \\
\pm 0,25\end{array}$ & & & & \\
\hline 1 & $\begin{array}{l}\text { Płuczka inwersyjna } \\
+ \text { ił mioceński } \\
+ \text { gilsonit }\end{array}$ & $\begin{array}{r}10,0 \\
2,0\end{array}$ & 1400 & 45 & 56 & 10,5 & $3,8 / 4,8$ & 0,4 & 690 \\
\hline
\end{tabular}

powierzchni rotora tworzono z płuczki inwersyjnej opracowanej w INiG - PIB (tablica 1).

W wyniku przeprowadzonych badań eksperymentalnych łączenia wybranych środków powierzchniowo czynnych z rozpuszczalnikami i substancjami o właściwościach myjących otrzymano wstępne składy mikroemulsji, które zastosowano do usuwania osadów olejowych z powierzchni metalowych.

Przeprowadzone pierwsze testy zmywania osadów płuczkowych z cylindra rotora wykazały, że skuteczność cieczy przemywającej zależy od jej składu. Za pomocą cieczy przemywającej nr 1 po czasie 10 minut usunięto około 50\% osadu (tablica 2, fotografia 2), poprzez zastosowanie cieczy przemywającej nr 3 wyeliminowano około $60 \%$ osadu (tablica 2, fotografia 4), natomiast najmniejszą efektywnością w działaniu wykazała się ciecz nr 2, która usunęła po 10 minutach tylko około $20 \%$ osadu (tablica 2, fotografia 3). W związku
Tablica 2. Wymywanie osadów płuczkowych z powierzchni rotora wiskozymetru Ofite 900 przez mieszaniny środków powierzchniowo czynnych

\begin{tabular}{|c|c|c|}
\hline Lp. & $\begin{array}{c}\text { Skład cieczy } \\
\text { przemywającej } \\
{[\%]}\end{array}$ & $\begin{array}{c}\text { Stopień wymycia osadów } \\
\text { płuczkowych z powierzchni } \\
\text { metalowej rotora } \\
{[\%]}\end{array}$ \\
\hline \multirow{3}{*}{1.} & $\mathrm{PNP}-7$ & \\
& $\mathrm{AS} 30-10$ & 50 \\
$\mathrm{RL}-5$ & \\
\hline \multirow{2}{*}{$\mathrm{H}_{2} \mathrm{O}-8$} & \\
\hline & $\mathrm{PNB}-7$ & 20 \\
\hline 3. & $\mathrm{~S} 270-15$ & \\
& $\mathrm{H}_{2} \mathrm{O}-8$ & \\
& $\mathrm{BDG}-8$ & \\
& $\mathrm{AS} 30-10$ & \\
& $\mathrm{~S} 225-5$ & \\
\hline
\end{tabular}




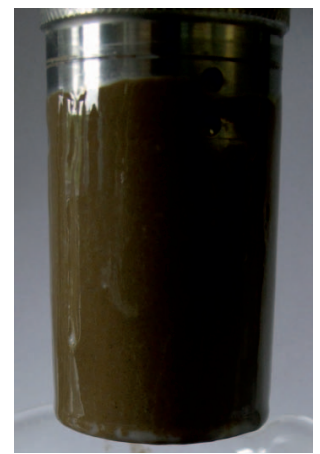

Fot. 1. Osad płuczkowy wytworzony na powierzchni rotora wiskozymetru

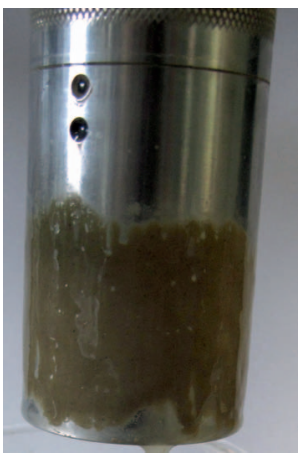

Fot. 2. Rotor wiskozymetru po oddziaływaniu cieczy przemywającej nr 1
Tablica 3. Wyniki pomiaru kąta zwilżania płytek metalowych po oddziaływaniu wodnych roztworów środków powierzchniowo czynnych

\begin{tabular}{|c|c|c|}
\hline Lp. & Rodzaj roztworu & Uśredniony kąt zwilżania, $\theta\left[{ }^{\circ}\right]$ \\
\hline 1 & $1 \%$ r-r NL6 & 15,8 \\
\hline 2 & $1 \%$ r-r IT8 & 11,2 \\
\hline 3 & $1 \%$ r-r ID5 & 6,7 \\
\hline 4 & $1 \%$ r-r NL8 & 8,7 \\
\hline 5 & $1 \%$ r-r IT6 & 17,2 \\
\hline 6 & woda & 58,2 \\
\hline 7 & olej B11 & 71,0 \\
\hline
\end{tabular}

NL8 i IT8. Tutaj średnie kąty zwilżania wynosiły odpowiednio 8,7 i 11,2 (tablica 3). Natomiast najwyższą wartość kąta zwilżania posiadał środek IT6, którego kąt zwilżania osiągnął wartość $17,2^{\circ}$ (tablica 3). Dla płytki metalowej po wcześniejszym oddziaływaniu wody uzyskaliśmy średni kąt zwilżania wynoszący $58,2^{\circ}$, a dla oleju mineralnego B11, będącego głównym składnikiem płuczki inwersyjnej - $71^{\circ}$ (tablica 3). Uwzględniając wyniki badań kąta zwilżania, przy którym odnotowano najniższe wartości, wybrano środek zwilżający ID5, który zastosowano w składzie cieczy przemywającej. Dzięki wykorzystaniu środka zwilżającego ID5 uzyskano zwiększenie efektywności zmywania zanieczyszczeń z powierzchni metalowych. W tablicy 4 zamieszczono wyniki usunięcia osadów płuczkowych z powierzchni rotora wiskozymetru przez opracowane ciecze przemywające (mikroemulsje).

Przy zastosowaniu mikroemulsji B i mikroemulsji G jako cieczy przemywających (tablica 4) uzyskano 100-procentowe oczyszczenie powierzchni rotora. Ilości usuniętych osadów z powierzchni cylindra rotora wynosiły odpowiednio 11,2 i 11 g (tablica 4). Należy zaznaczyć, iż taki stopień oczyszczenia rotora z osadu uzyskano po czasie 3 minut oddziaływania cieczy przemywających (fotografie 6 i 8). W przypadku mikroemulsji I otrzymano tylko częściowe oczyszczenie

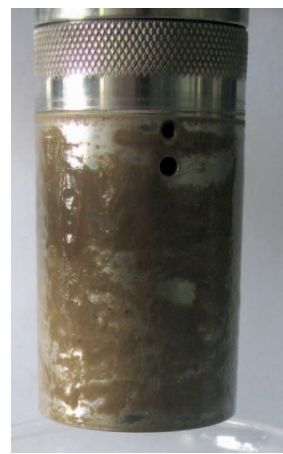

Fot. 3. Rotor wiskozymetru po oddziaływaniu cieczy przemywającej nr 2

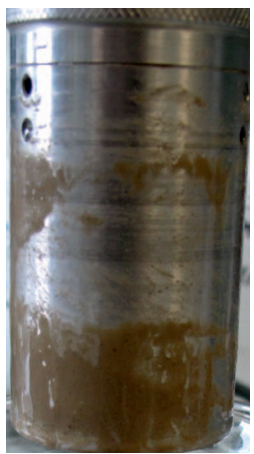

Fot. 4. Rotor wiskozymetru po oddziaływaniu cieczy przemywającej nr 3 powierzchni rotora (fotografia 7), ilość usuniętego osadu przez ciecz przemywającą wynosiła $6 \mathrm{~g}$, co stanowiło około $30 \%$ usuniętego osadu (tablica 4 ). Na podstawie przeprowadzonych badań wybrano 2 składy cieczy przemywających: mikroemulsję B i mikroemulsję G, przy których uzyskano największą efektywność w usuwaniu osadów płuczkowych $\mathrm{z}$ metalowej powierzchni rotora.

Tablica 4. Wymywanie osadów płuczkowych z powierzchni rotora wiskozymetru Ofite 900 przez ciecze przemywające

\begin{tabular}{|c|c|c|c|}
\hline Lp. & $\begin{array}{c}\text { Skład cieczy } \\
\text { przemywającej }\end{array}$ & $\begin{array}{c}\text { Ilość usuniętego } \\
\text { osadu z powierzchni } \\
\text { rotora } \\
{[\mathrm{g}]}\end{array}$ & $\begin{array}{c}\text { Stopień wymycia } \\
\text { zanieczyszczeń } \\
{[\%]}\end{array}$ \\
\hline 1 & Mikroemulsja A & 8,7 & 80 \\
\hline 2 & Mikroemulsja B & 11,2 & 100 \\
\hline 3 & Mikroemulsja C & 9,9 & 90 \\
\hline 4 & Mikroemulsja D & 9,0 & 85 \\
\hline 5 & Mikroemulsja G & 11,0 & 100 \\
\hline 6 & Mikroemulsja H & 5,4 & 50 \\
\hline 7 & Mikroemulsja I & 3,4 & 30 \\
\hline
\end{tabular}

Następnie przeprowadzono badania mające na celu określenie optymalnego czasu oddziaływania opracowanych cieczy przemywających do usunięcia osadów olejowych wytworzonych z płuczki inwersyjnej z powierzchni metalowej rotora. Wyniki badania przedstawione na rysunku 2 wskazują na dużą skuteczność w działaniu opracowanych cieczy w usuwaniu osadów płuczkowych z powierzchni metalowej rotora. Mikroemulsja B już po 1 minucie oddziaływania usunęła około $95 \%$ osadu, by po 2 minutach prawie w całości $(99 \%)$ wyeliminować osad płuczkowy. Można przyjąć, że całkowity czas potrzebny do usunięcia osadu z rotora wiskozymetru to około 3 minuty (rysunek 2). Mikroemulsja G charakteryzowała się nieznacznie gorszą efektywnością w likwidacji zanieczyszczeń olejowych. Po 1 minucie mikroemulsja G usunęła około $90 \%$, a po 3 minutach około $98 \%$ osadu. 


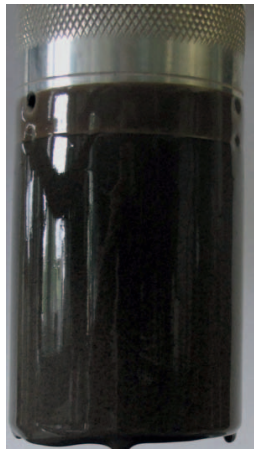

Fot. 5. Osad płuczkowy wytworzony na powierzchni rotora wiskozymetru

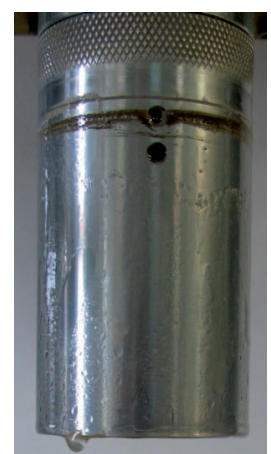

Fot. 6. Rotor wiskozymetru po oddziaływaniu mikroemulsji B
Po czasie oddziaływania wynoszącym 4 minuty mikroemulsja G wyeliminowała $100 \%$ osadu z powierzchni metalowej rotora (rysunek 2).

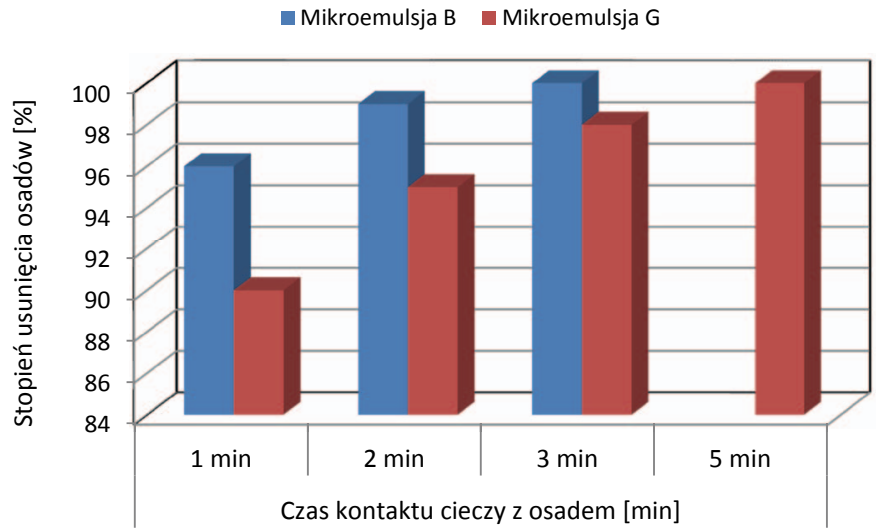

Rys. 2. Wpływ czasu oddziaływania cieczy przemywającej na stopień usunięcia osadów płuczkowych

Kolejną bardzo ważną właściwością cieczy przemywających, oprócz rozpuszczania zanieczyszczeń olejowych i usuwania powstałych osadów z płuczki inwersyjnej, jest przywrócenie przemywanym powierzchniom właściwości hydrofilowych. W związku z powyższym przeprowadzono dodatkowe badania kąta zwilżania na płytkach metalowych dla cieczy przemywających mikroemulsji B i G. Na płytkach metalowych najpierw został wytworzony osad z płuczki inwersyjnej, a następnie poddano je oczyszczaniu za pomoca cieczy przemywających. Dla porównania zostały wykonane również badania kąta zwilżania dla płytek metalowych po oddziaływaniu oleju i wody. Wyniki pomiaru kąta zwilżania płytek metalowych z zaadsorbowaną na ich powierzchni substancją przedstawiono na rysunku 3 .

Dla płytki metalowej zanurzonej w wodzie uzyskano średni kąt zwilżania wynoszący $58,2^{\circ}$ (rysunek 3 ). Po zastosowaniu oleju B11 kąt zwilżania wzrósł do $71^{\circ}$ (rysunek 3). Usunięcie z płytek metalowych osadu płuczkowego przez przemywanie ich w mikroemulsji B spowodowa-

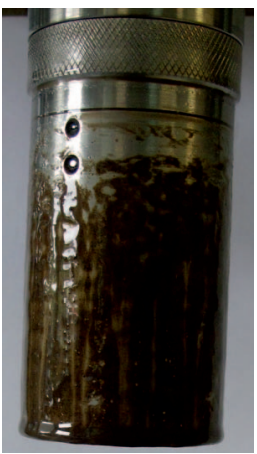

Fot. 7. Rotor wiskozymetru po oddziaływaniu mikroemulsji I

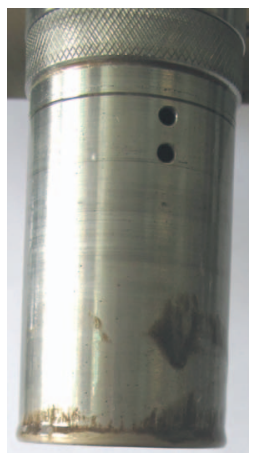

Fot. 8. Rotor wiskozymetru po oddziaływaniu mikroemulsji G ło obniżenie kąta zwilżania do $19,9^{\circ}$ (rysunek 3). Podobną wartość kąta zwilżania $\left(24,4^{\circ}\right)$ uzyskano dla mikroemulsji G (rysunek 3). Zastosowanie mikroemulsji B i G jako cieczy przemywających pozwoliło na zmianę zwilżalności i nadanie przemywanym metalowym płytkom właściwości hydrofilowych. W dalszych badaniach wybrany skład mikroemulsji B zastosowano do sporządzenia składów cieczy przemywających i rozdzielających.

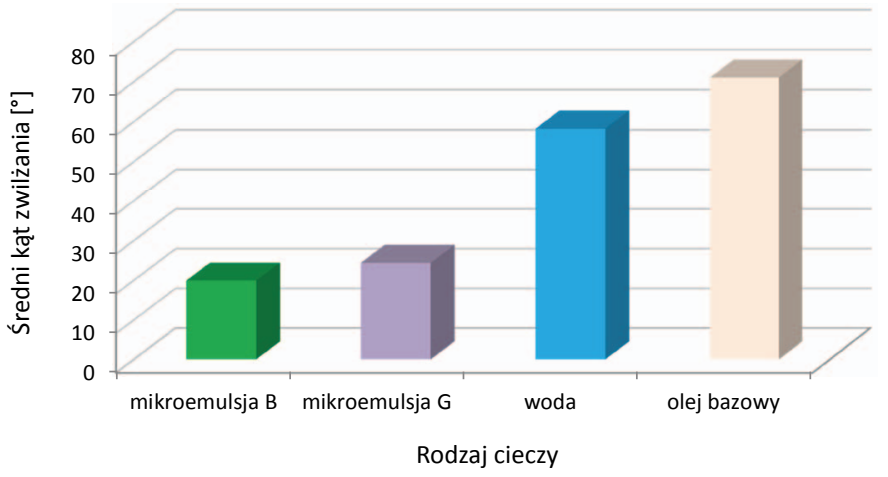

Rys. 3. Wyniki pomiaru kąta zwilżania dla płytek metalowych po usunięciu z nich osadów olejowych za pomocą cieczy przemywających i dla porównania po oddziaływaniu wody i oleju

Efektywność usuwania osadów z wykorzystaniem cieczy przemywających i rozdzielających z metalowych części rotora sprawdzono $\mathrm{w}$ dwóch wybranych systemach (system A i system B).

1. W systemie A usuwanie osadów powstałych z płuczki inwersyjnej prowadzono przez zastosowanie trzech cieczy:

- ciecz przemywającą nr 1 - wytworzony osad na powierzchni metalowej rotora przemywano przez 3 minuty,

- ciecz przemywającą nr 2 (oczyszczająca) - usuwanie osadu prowadzono przez 4 minuty,

- ciecz przemywającą $\mathrm{nr} 3$ - przemywanie osadu trwało 3 minuty. 


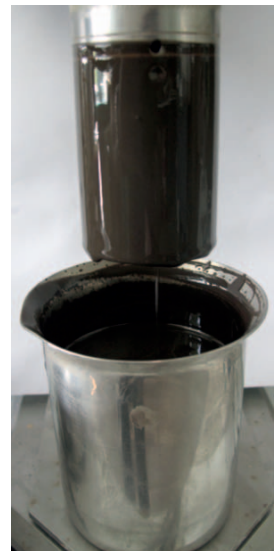

Fot. 9. Osad płuczkowy wytworzony na powierzchni rotora wiskozymetru

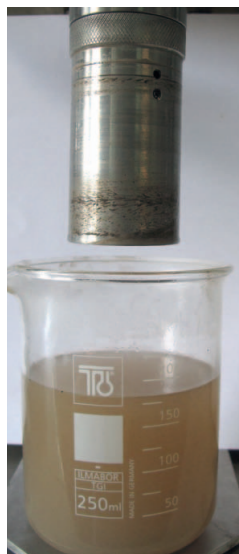

Fot. 10. Rotor wiskozymetru po oddziaływaniu cieczy przemywającej nr 1

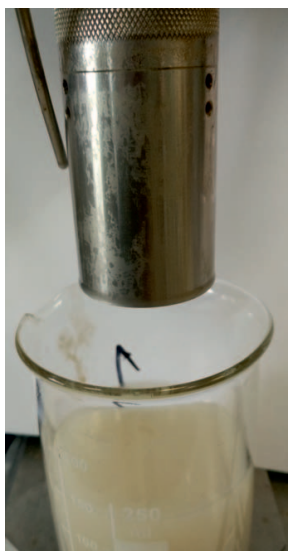

Fot. 11. Rotor wiskozymetru po oddziaływaniu cieczy przemywającej nr 2 w systemie A

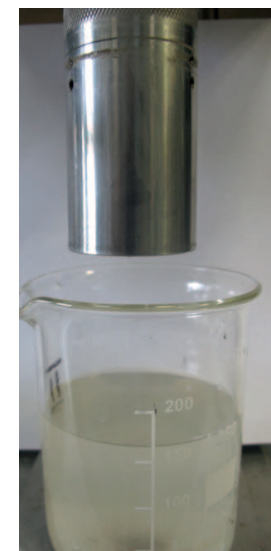

Fot. 12. Rotor wiskozymetru po oddziaływaniu cieczy przemywającej nr 3

Osad na powierzchni rotora wiskozymetru został wytworzony z płuczki inwersyjnej o gęstości $1400 \mathrm{~kg} / \mathrm{m}^{3}$ (tablica 1, fotografia 9 i 13). Pierwszą cieczą zastosowaną do usuwania osadu płuczkowego była ciecz przemywająca nr 1 . Jej zadanie polegało na rozcieńczeniu zanieczyszczeń olejowych przylegających do powierzchni metalowej rotora. Odpowiedni dobór składu cieczy przemywającej pozwolił już po 3 minutach erodowania wirowego na prawie całkowite usunięcie osadu (około 98\% - fotografia 10). Po upływie 3 minut usuwanie osadu kontynuowano za pomocą cieczy przemywającej nr 2 (oczyszczającej) przez kolejne 4 minuty. Ciecz oczyszczająca w tym czasie usunęła resztki pozostawionego osadu płuczkowego (fotografia 11). Dodatkowo rotor wiskozymetru przepłukano cieczą przemywającą $\mathrm{nr} 3$, która nadała powierzchni metalowej odpowiednią zwilżalność (fotografia 12).

2. W systemie B do usuwania osadów płuczkowych zastosowano dwie ciecze:

- ciecz rozdzielającą o gęstości $1500 \mathrm{~kg} / \mathrm{m}^{3}$, założony czas kontaktu z osadem wynosił 6 minut,

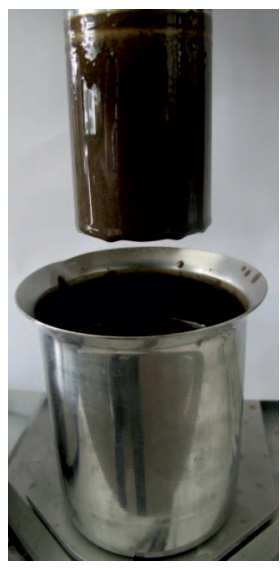

Fot. 13. Osad płuczkowy wytworzony na powierzchni rotora wiskozymetru

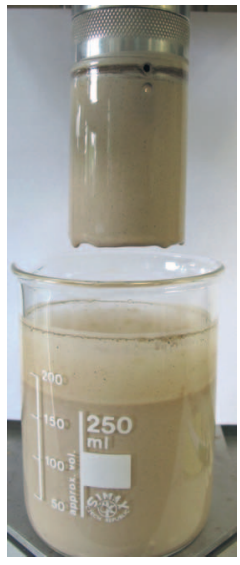

Fot. 14. Rotor wiskozymetru po oddziaływaniu cieczy rozdzielającej o gęstości $1500 \mathrm{~kg} / \mathrm{m}^{3}$
- ciecz przemywającą nr 2 (oczyszczającą) - przemywanie osadu wynosiło 4 minuty.

W pierwszej kolejności w systemie B wytworzony osad płuczkowy próbowano usunąć przez przemywanie go cieczą rozdzielającą o gęstości $1500 \mathrm{~kg} / \mathrm{m}^{3}$. Oddziaływanie cieczy rozdzielającej na powstały osad płuczkowy przez 6 minut spowodowało częściowe jego usunięcie z naniesieniem na metalową powierzchnię rotora nowej warstwy osadu barytowego (fotografia 14). Po upływie 6 minut zmieniono ciecz rozdzielającą na ciecz przemywającą nr 2 i kontynuowano usuwanie osadu przez kolejne 4 minuty. Po zakończonym procesie oczyszczania, który trwał 10 minut, stwierdzono całkowite wyeliminowanie osadu płuczkowego z powierzchni rotora, jak również z przestrzeni pierścieniowej pomiędzy cylindrem rotora a bobem wiskozymetru (fotografia 15).

\section{Badania przyczepności na kontakcie kamień cementowy-skata}

Badanie to pozwala określić wpływ opracowanych cieczy przemywających na stopień usunięcia osadów po płucz-

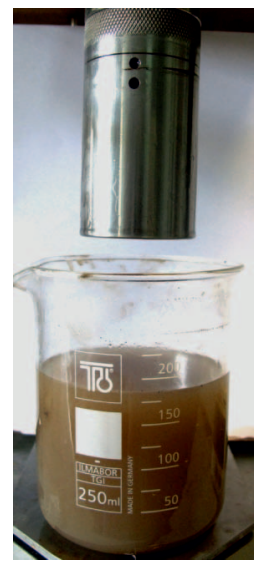

Fot. 15. Rotor wiskozymetru po oddziaływaniu cieczy ce inwersyjnej oraz na jakość zacementowania. Pierwszym krokiem było wyznaczenie przyczepności wzorcowej, do której odnoszono wyniki kolejnych badań. Uzyskane wartości przyczepności do skały i stali zostały ujęte w opracowaniu jako wartość przyczepności wzorcowej (wyjściowej), do której odnoprzemywającej nr 2 w systemie B szono i porównywano 
Tablica 5. Przyczepność na kontakcie kamień cementowy-skała dla próbki wzorcowej oraz dla próbki po oddziaływaniu płuczki inwersyjnej

\begin{tabular}{|l|c|c|c|c|}
\hline \multicolumn{1}{|c|}{ Przyczepność na kontakcie kamień cementowy-skała } & \multicolumn{2}{c|}{ Dla próbki wzorcowej } & \multicolumn{2}{c|}{$\begin{array}{c}\text { Dla próbki po oddziaływaniu } \\
\text { płuczki inwersyjnej }\end{array}$} \\
\hline Temperatura $\left[{ }^{\circ} \mathrm{C}\right]$ & \multicolumn{2}{|c|}{50} & \multicolumn{3}{|c|}{50} \\
\hline Czas sezonowania [dni] & 2 & 7 & 2 & 7 \\
\hline Siła zerwania przyczepności [kN] & 3,2 & 3,8 & 0,2 & 0,3 \\
\hline Przyczepność na kontakcie kamień cementowy-skała [MPa] & 0,93 & 1,1 & 0,06 & 0,09 \\
\hline
\end{tabular}

wyniki uzyskane po zastosowaniu płuczki inwersyjnej i oddziaływaniu opracowanych cieczy przemywających. W tablicy 5 przedstawione zostały wyniki badań przyczepności kamienia cementowego do próbki piaskowa (próbka wzorcowa) oraz do rdzenia piaskowca, na powierzchni którego wytworzone zostały osady z płuczki inwersyjnej. Do badań laboratoryjnych wykorzystano zaczyn cementowy sporządzony według składu, który został zastosowany do cementowania rur okładzinowych $95 / 8$ " w otworze T. Natomiast osady tworzono z płuczki inwersyjnej o stosunku w/o 20/80, obciążonej barytem do gęstości $1400 \mathrm{~kg} / \mathrm{m}^{3}$ i skażonej $10 \%$ iłu mioceńskiego imitującego zwierconą fazę stałą (tablica 1).

Uzyskane wyniki przyczepności zaczynu cementowego do skały po dwóch dniach sezonowania dla próbki wzorcowej wyniosły 0,93 MPa; po siedmiu dniach nastąpił niewielki wzrost - do wartości 1,1 MPa (tablica 5, rysunek 4). Przyczepność kamienia cementowego do skały po wcześniejszym oddziaływaniu płuczki inwersyjnej spowodowała znaczne obniżenie tego parametru do wartości $0,06 \mathrm{MPa}$ po 2 dniach hydratacji cementu, a po siedmiu do $0,09 \mathrm{MPa}$ (tablica 5, rysunek 4). Osady wytworzone przez płuczkę inwersyjną na rdzeniach piaskowca wywołały spadek przyczepności o $93,7 \%$ po dwóch dniach oraz o $92,1 \%$ po siedmiu dniach sezonowania. Wytworzony osad na rdzeniu piaskowca uniemożliwił związanie kamienia cementowego i skały. Przeprowadzone badanie wskazuje na konieczność sto- sowania przed zabiegiem cementownia cieczy przemywających skutecznie usuwających osady płuczkowe wytworzone podczas wiercenia otworu. Brak zastosowania tego rodzaju cieczy lub nieodpowiedni ich dobór uniemożliwia związanie kamienia cementowego i ściany otworu wiertniczego.

Do określenia wpływu właściwości cieczy wiertniczych na stopień uszczelnienia przestrzeni pierścieniowej na kontakcie kamień cementowy-skała wybrano jako ciecz przemywającą mikroemusję B. Charakteryzowała się ona największą efektywnością w usuwaniu osadów płuczkowych. Następnie mikroemulsję B zastosowano do usuwania wytworzonych osadów płuczkowych z rdzenia skalnego w dwóch systemach płukania otworu (tablica 6).

W systemie A do usuwania osadów płuczkowych zastosowano ciecz przemywającą nr 1 . Czas kontaktu tej cieczy ze skałą został ustalony na podstawie wcześniejszych badań i wyniósł 6 minut. Drugą cieczą użytą w systemie A do usuwania osadów płuczkowych była mikroemulsja B, czas kontaktu mikroemulsji ustalono na 9 minut. Natomiast jako trzecią zastosowano ciecz przemywająca nr 3. Przemywanie osadu na powierzchni rdzenia skalnego w systemie płukania A pozwoliło na zwiększenie przyczepności związania kamienia cementowego do skały po dwóch dniach sezonowania do wartości $0,58 \mathrm{MPa}$, a po siedmiu dniach do $0,93 \mathrm{MPa}$ (tablica 6 , rysunek 4 , fotografie 16-19). W stosunku do przyczepności wzorcowej jej wartość obniżyła się tylko o niecałe $16 \%$.

Tablica 6. Rodzaje cieczy przemywających zastosowanych do usuwania osadów z płuczki inwersyjnej ze skały w dwóch systemach płukania

\begin{tabular}{|c|c|c|c|c|}
\hline Rodzaj systemu płukania & \multicolumn{2}{|c|}{ System A } & \multicolumn{2}{|c|}{ System B } \\
\hline \multirow{2}{*}{ Zakładany czas kontaktu cieczy przemywającej ze ścianą otworu [min] } & \multicolumn{2}{|c|}{ Ciecz przemywająca nr 1} & \multicolumn{2}{|c|}{ Ciecz rozdzielająca $\mathrm{nr} 1$} \\
\hline & \multicolumn{2}{|c|}{$6 \mathrm{~min}$} & \multicolumn{2}{|c|}{$15 \mathrm{~min}$} \\
\hline \multirow{2}{*}{ Zakładany czas kontaktu cieczy przemywającej ze ścianą otworu [min] } & \multicolumn{2}{|c|}{ Ciecz przemywająca nr 2} & \multicolumn{2}{|c|}{ Ciecz przemywająca nr 2} \\
\hline & \multicolumn{2}{|c|}{$9 \mathrm{~min}$} & \multicolumn{2}{|c|}{$5 \mathrm{~min}$} \\
\hline \multirow{2}{*}{ Zakładany czas kontaktu cieczy przemywającej ze ścianą otworu [min] } & \multicolumn{2}{|c|}{ Ciecz przemywająca nr 3} & \multirow[b]{3}{*}{2} & \multirow[b]{3}{*}{7} \\
\hline & \multicolumn{2}{|c|}{$5 \mathrm{~min}$} & & \\
\hline Czas sezonowania próbki [dni] & 2 & 7 & & \\
\hline Siła zerwania przyczepności [kN] & 2 & 3,2 & 1,8 & 2,9 \\
\hline Przyczepność na kontakcie kamień cementowy-skała [MPa] & 0,58 & 0,93 & 0,52 & 0,83 \\
\hline Procentowa zmiana przyczepności w stosunku do przyczepności bazowej [\%] & 37,5 & 15,8 & 43,75 & 23,7 \\
\hline
\end{tabular}




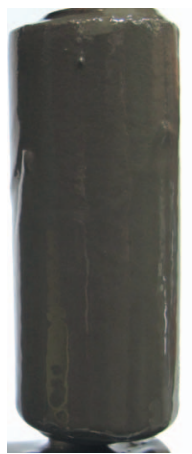

Fot. 16. Osad płuczkowy wytworzony na rdzeniu piaskowca

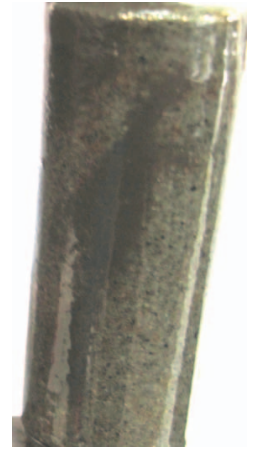

Fot. 17. Rdzeń piaskowca po przemyciu cieczą nr 1 w systemie A

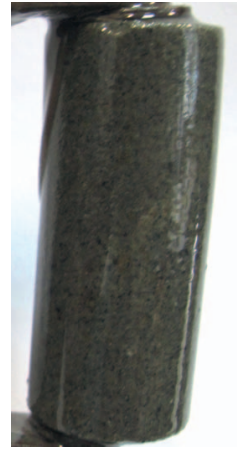

Fot. 18. Rdzeń piaskowca po przemyciu cieczą nr 2 w systemie A

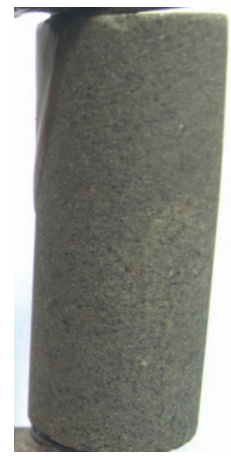

Fot. 19. Rdzeń piaskowca po przemyciu cieczą nr 3 w systemie A

W systemie płukania B zastosowano tylko dwie ciecze. Pierwszą cieczą przemywającą po płuczce inwersyjnej o gęstości $1400 \mathrm{~kg} / \mathrm{m}^{3}$ była ciecz rozdzielającą o gęstości $1500 \mathrm{~kg} / \mathrm{m}^{3}$. Bufor barytowy przemywał osad wytworzony na rdzeniu piaskowca przez 15 minut. Po zastosowaniu cieczy przemywającej nr 1 zauważono częściowe rozfrakcjonowanie osadu płuczkowego i pokrycie rdzenia skalnego osadem barytowym z cieczy nr 1 . Następnie dalsze usuwanie osadu prowadzono za pomocą cieczy przemywającej $\mathrm{nr} 2$.

Czas przemywania osadu przez ciecz nr 2 wynosił 5 minut. Następnie przemyte próbki skalne zalano zaczynem cementowym. Po sezonowaniu próbek przez dwa dni wartość przyczepności wynosiła $0,52 \mathrm{MPa}$, a po siedmiu dniach $0,83 \mathrm{MPa}$, zatem przyczepność wzorcowa obniżyła się odpowiednio o $43,75 \%$ i $23,7 \%$ (tablica 6, rysunek 4, fotografie 20-22). Zastosowanie cieczy przemywających w systemie płukania B przyczyniło się do ponad 10-krotnego wzrostu przyczepności kamienia cementowego do skały w porównaniu z próbką skalną bez procesu oczyszczania.

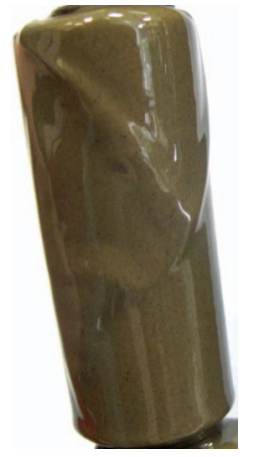

Fot. 20. Osad płuczkowy wytworzony na rdzeniu piaskowca w systemie B

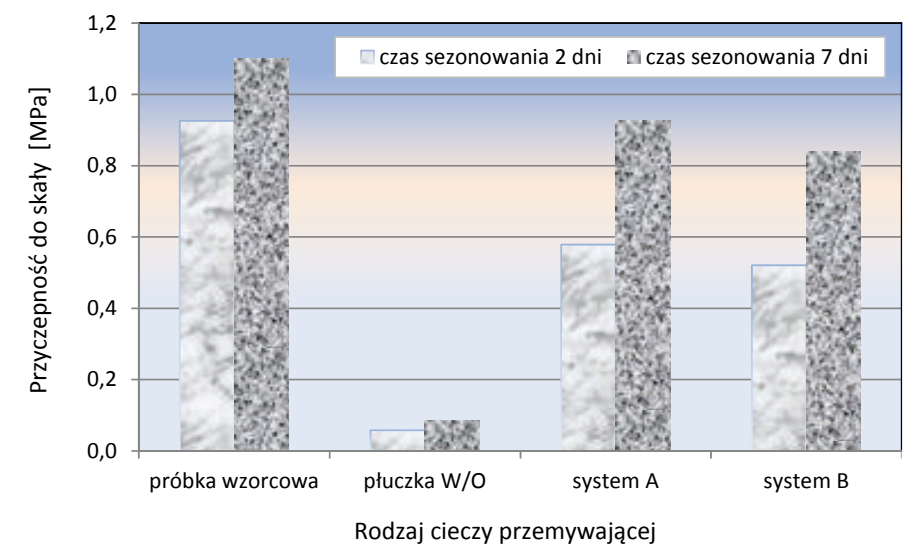

Rys. 4. Wartości przyczepności na kontakcie kamień cementowy-skała dla próbki wzorcowej, próbki po oddziaływaniu płuczki inwersyjnej oraz dla próbki po zastosowaniu mikroemulsji B w dwóch systemach płukania

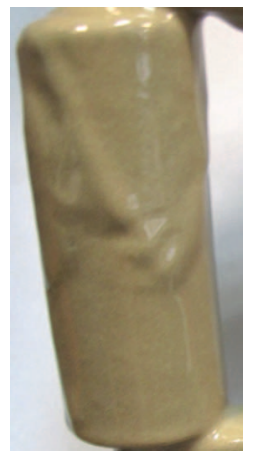

Fot. 21. Rdzeń piaskowca po przemyciu cieczą nr 1 W systemie B

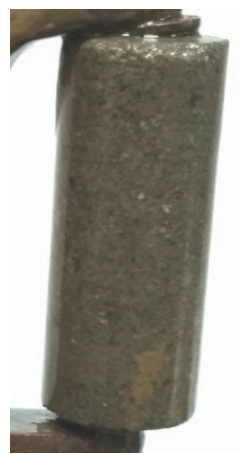

Fot. 22. Rdzeń piaskowca po przemyciu cieczą nr 2 w systemie B

\section{Podsumowanie}

Przeprowadzone badania przyczepności kamienia cementowego do skały potwierdziły dużą efektywność w działaniu opracowanych cieczy przemywających w różnych systemach płukania otworu. Prawie we wszystkich przypadkach po zastosowaniu cieczy przemywających uzyskano zwiększenie stopnia związania kamienia cementowego i skały. Najlep- sze efekty oczyszczania rdzeni skalnych z olejowych osadów płuczkowych otrzymano, stosując trzy ciecze przemywające zawierające dodatek mikroemulsji B. Przy wykorzystaniu tego rodzaju cieczy uzyskano nawet dziesięciokrotny wzrost przyczepności kamienia cementowego do skały (w porównaniu z próbką skały niepoddawanej procesowi 
oczyszczania), co należy uznać za wynik bardzo dobry, porównywalny z wynikami przyczepności kamienia cementowego do skały uzyskiwanymi po zastosowaniu do wiercenia płuczek wodnodyspersyjnych. Bardzo dobre wyniki otrzymano także, stosując do oczyszczania olejowych osadów płuczkowych tylko dwie ciecze przemywające. W wyniku użycia ww. cieczy przyczepność związanego kamienia cementowego do skały obniżyła się tylko o $23,7 \%$ w stosunku do przyczepności wzorcowej. Przeprowadzone badania porównawcze opracowanych cieczy przemywających wykazały znacznie większą efektywność w usuwaniu zanieczyszczeń olejowych w porównaniu z cieczami przemywającymi zastosowanymi w warunkach otworowych. Należy również podkreślić, że większą skuteczność w usuwaniu osadów uzyskano przy znacznie krótszych czasach oddziaływania cieczy przemywających.

Poprzez zastosowanie nowego rodzaju cieczy przemywającej przed zabiegiem cementowania możliwe będzie zmniej- szenie ilości zatłaczanych cieczy wiertniczych oraz skrócenie czasów płukania otworu, a co najważniejsze - zwiększenie efektywności w usuwaniu osadów płuczkowych z przestrzeni pierścieniowej, zmierzającej do znacznej poprawy jakości cementowania otworu wiertniczego po płuczce olejowodyspersyjnej (zwiększenia przyczepności zaczynu cementowego do ścian otworu i lepszego wypełnienia przestrzeni pierścieniowej).

Ostateczny wybór sposobu oczyszczania ścian otworu i rur okładzinowych z zanieczyszczeń olejowych po płuczce inwersyjnej przed zabiegiem cementowania wymaga przeprowadzenia dodatkowych badań sprawdzających, uwzględniających rodzaj i właściwości stosowanej do wiercenia płuczki wiertniczej oraz proponowany skład i właściwości zaczynu cementowego. Przedstawione sposoby usuwania zanieczyszczeń olejowych z płuczki inwersyjnej należy modyfikować i dostosowywać do warunków geologiczno-technicznych występujących na danym terenie wierceń.

Prosimy cytować jako: Nafta-Gaz 2017, nr 5, s. 302-311, DOI: 10.18668/NG.2017.05.02

Artykuł nadesłano do Redakcji 8.12.2016 r. Zatwierdzono do druku 24.02.2017 r.

Artykuł powstał na podstawie pracy statutowej pt.: Nowe rodzaje cieczy przemywających osady z pluczki inwersyjnej przed zabiegiem cementowania otworów wiertniczych - praca INiG - PIB na zlecenie MNiSW; nr zlec. 0037/KW/16, nr archiwalny: DK-4100-37/16.

\section{Literatura}

[1] Addagalla A.K.V., Kosandar B.A., Lawal I.G., Jadhav P.B., Imran A., El-Araby M.S., Al Saqer Q.R., Ansari A., Pino R., Gad-Alla A.E., Olivaresantunez T.: Remediation of severly damaged wells using mesophase technology: case histories, Saudi Arabia. SPE-178156-MS, 2016, s. 1-13.

[2] Brege J.J., Amin El Sherbeny W.I., Quintero L., Jones T.A.: Using microemulsion technology to remove oil-based mud in wellbore displacement and remediation applications. SPE-150237-MS, 2012, s. 1-8.

[3] Jasiński B.: Badania nad zastosowaniem emulsji olejowo-wodnych jako cieczy roboczych o obniżonej gęstości. Nafta-Gaz 2012, nr 12, s. 1155-1164.

[4] Jasiński B.: Ocena wpływu cieczy przemywających na jakość zacementowania rur $w$ otworze wiertniczym po użyciu płuczki glikolowo-potasowej. Nafta-Gaz 2016, nr 6, s. 413-421, DOI: $10.18668 / \mathrm{NG} .2016 .06 .04$.

[5] Kefi S., Pershikova E., Docherty K., Barral Q., Droger N., De La Mothe L.R., Khaifallah I.: Successful cementing based on new design methodology for displacement of non-aqueous drilling fluid. SPE-167948-MS, 2014, s. 1-12.

[6] Mahmoudkhani A., O’Neil B., Wylde J.J., Kakadjian S., Bauer M.: Microemulsions as flowback aids for enhanced oil and gas recovery after fracturing, myth or reality: A Turnkey study to determine the features and benefits. SPE-173729-MS, 2015, s. 1-18.

[7] McDonald M., Xianglian L., Lim B.: A formulated silicate-based preflush \& spacer for improved wellbore cleaning and wetting. AADE-14-FTCE-55, 2014, s. 1-6.

[8] Pernites R., Khammar M., Santra A.: Robust spacer system for water and oil based mud. SPE-174005-MS, 2015, s. 1-16.

[9] Pietrangeli G., Quintero L., Gonzalez Y.: In-situ microemulsions enhance removal of non-aqueous drilling fluid in Gulf of Guinea Wells. SPE-174239-MS, 2015, s. 1-16.
[10] Salehi S., Ghalambor A., Saleh F.K., Hussmann S.: Study of filtrate and mud cake characterization in HPHT: Implications for formation damage control. SPE-174273-MS, 2015, s. 1-9.

[11] See C.H., Saphanuchart W., Nadarajan S., Lim C.N.: Nanoemulsion for non-aqueous mud removal in wellbore. SPE-149088-MS, 2011, s. 1-10.

[12] Shadravan A., Ghasemi M., Alfi M.: Zonal isolation in geothermal wells. Proceedings, Fortieth workshop on geothermal reservoir engineering Stanford University, 2015, s. 1-10.

[13] Shadravan A., Narvaez G., Alegria A., Carman P., Perez C., Erger R.: Engineering the mud-spacer-cement rheological hierarchy improves wellbore integrity. SPE-173534-MS, 2015, s. 1-14.

[14] Taoutaou S., Goh S.H., Vargas Bermea J.A., Vinaipanit M., McClure J.: Achieving zonal isolation by using new-generation mud removal chemistry and design methodology to displace non-aqueous drilling fluid. SPE-176061-MS, 2015, s. 1-19.

[15] Zanten R.V., Deen L., Ezzat D.: Successful field applications of surfactant nanotechnology to displace oil-based drilling fluids for completion operations. AADE-11-NTCE-1, 2011, s. 1-6.

[16] Zanten R.V., Ezzat D.: Surfactant nanotechnology offers new method for removing oil-based mud residue to achieve fast, effective wellbore cleaning and remediation. SPE-127884-MS, 2010, s. $1-8$.

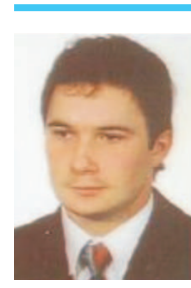

Mgr inż. Sławomir BŁAŻ

Starszy specjalista badawczo-techniczny w Zakładzie Technologii Wiercenia.

Instytut Nafty i Gazu - Państwowy Instytut Badawczy

ul. Lubicz 25 A

31-503 Kraków

E-mail: slawomir.blaz@inig.pl 